\title{
EXTENSIVE URETERAL STRICTURE AFTER PERCUTANEOUS NEPHROLITHOTOMY
}

\author{
Antonio Corrêa Lopes Neto, Mário Henrique Elias de Mattos, Matheus Neves Ribeiro da Silva \\ and Eric Roger Wroclawski.
}

Endourology section of the Discipline of Urology of the ABC Medical School. Santo André. Brazil.

\begin{abstract}
Summary.- OBJECTIVE: To present a previously unreported long term complication of percutaneous nephrolithotomy for exclusive renal stone.

METHODS/RESULTS: A 30-years-old woman underwent percutaneous nephrolithotomy for a obsrtuctive pelvic stone, through inferior calix access achieving a stone free status. During the procedure occurred an inadvertent pelvis perforationan, but the early evolution was otherwise uneventful. Patient was asymptomatic during the follow-up. However, a urinary ultrasound disclosed important pielocalyceal dilation, and further investigation demonstrated extensive proximal ureteral stricture.
\end{abstract}

CONCLUSION: Ureteral stricture may rarely occur as a late complication of percutaneous nephrolithotomy. A review of the literature of this quite uncommon complication was performed and the authors discuss the possible etiology and preventive measures.

Keywords: Percutaneous nephrolithotomy. Ureteral stricture.

Resumen.- OBJETIVO: Presentar una complicación a largo plazo no comunicada previamente de la nefrolitectomía percutánea en el tratamiento de la litiasis renal única.

MÉTODOS/RESULTADOS: Mujer de 30 años con litiasis piélica obstructiva que fue sometida a nefrolitectomía percutánea a través de un acceso por cáliz inferior, consiguiendo la resolución. Durante la intervención hubo una perforación de pelvis inadvertida; la evolución temprana fue, por lo demás, sin complicaciones. La paciente permaneciera sintomática durante el seguimiento. Sin embargo, una ecografía de aparato urinario descubrió una importante dilatación pielocalicial, y las pruebas diagnósticas posteriores demostraron una estenosis ureteral proximal larga.

CONCLUSIONES: Las estenosis ureteral pueden aparecer rara vez como complicaciones tardías de la nefrolitectomía percutánea. Realizamos una revisión de la literatura sobre esta complicación tan poco común y discutimos la posible etiología y medidas preventivas.

Palabras clave: Nefrolitectomía percuténea. Litiasis renal. 


\section{INTRODUCTION}

Percutaneous nephrolithotomy (PNL) is among main options for the treatment of renal calculi disease, especially larger stones. Although it is a minimally invasive technique, complications do occur. Proximal ureteral stricture is a rarely reported complication with controversial etiology, and in the cases so far reported, it always occur when PCN is used for proximal ureteral stones (1). The authors report a case of extensive proximal ureteral stricture after PCN performed for pelvic stone.

\section{CASE REPORT AND MANAGEMENT}

A 30-years-old woman presented to the ambulatory complaining of episodic left renal colic. Medical history disclosed no fever or any other symptoms suggestive of attending urinary infection. Urine exam showed pyuria, urine culture was negative and serum renal function tests were normal. Intravenous urography (IVU) identified simultaneous bilateral contrast elimination, a left $600 \mathrm{~mm}^{2}$ partially obstructive pelvic stone, and free ureteral drainage of contrast (Figure IA - B). Left percutaneous nephrolithotomy was then performed through inferior calyx puncture and dilation of the tract with semirigid Amplatz up 30Fr. It allowed easy visualization of the stone, which fulfilled renal pelvis. It was not possible to visualize the ureteropelvic junction (UPJ). During pneumatic fragmentation, a renal pelvis perforation occurred, with extravasation of some small fragments to the retro peritoneum. The whole stone mass was extracted from renal pelvis. $\mathrm{Ne}$ phrostomy tube was maintained for two weeks. Four months later the patient was asymptomatic. However, a urinary ultrasound disclosed important pielocalyceal dilation, with a normal parenquimal width. IVU showed left functional renal exclusion. Retrograde pyelography demonstrated extensive ureteral stricture and attending proximal dilation (Figure 2). A ureteral stent was left for three months, when a renal scan with DMSA disclosed only $13 \%$ of function in the left kidney. The patient underwent uneventful laparoscopic nephrectomy.

\section{DISCUSSION}

$\mathrm{PCN}$ is a standard urological procedure for treatment of large renal stones. Nevertheless, even in expert hands and use of suitable material, complication may occur. The most common are hemorrhage, collecting system perforation, adjacent organ
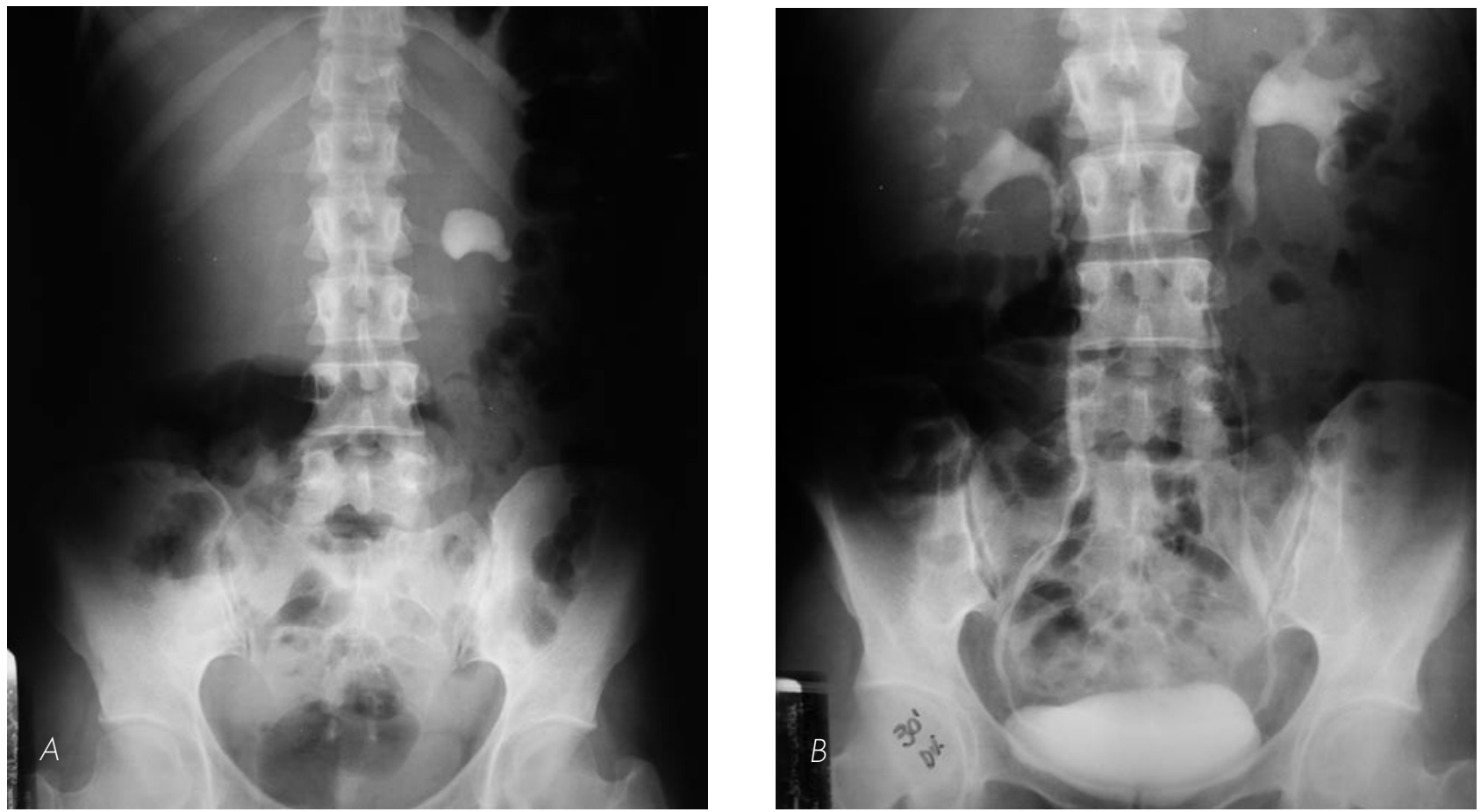

FIGURE IA-B. Excretory urography discloses a large pyelic stone with small calicial dilation.

Notice the ureteropelvic junction is widely open. 


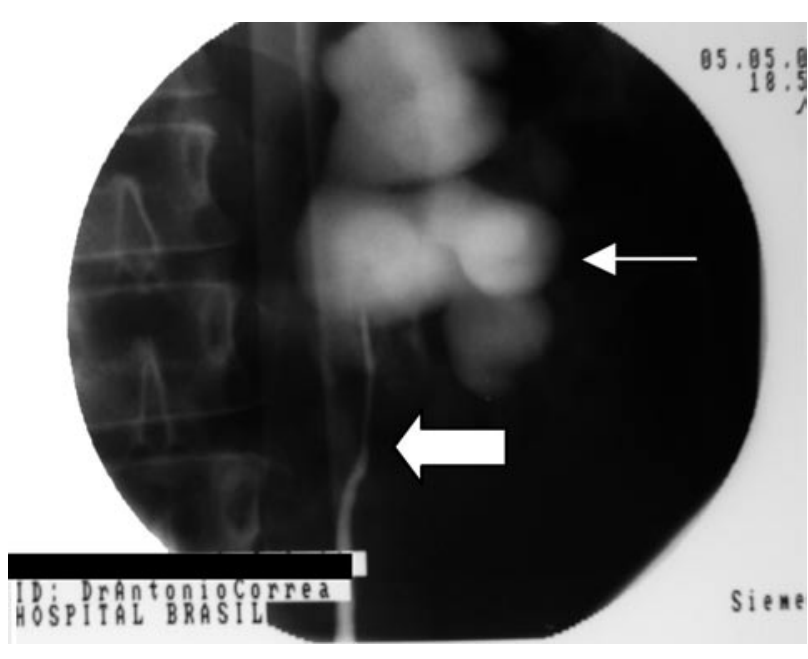

\begin{abstract}
FIGURE 2. Extensive proximal ureteral stricture (large arrow) with attending enormous collecting system dilation (narrow arrow).
\end{abstract}

injury and fistulas (urinary and vascular). Strictures of collecting system are estimated to occur in about $1 \%$ of patients, and almost always involve the UPJ or calicial infundibulum2. These strictures are attributed to: inflammatory response due to the stone, mucosal injury caused by endoscopic manipulation or perforation with attending extravasation of contaminated urine $(3,4)$.

In our experience, this is the first case of ureteral stricture after more than $130 \mathrm{PCN}$ performed. There are some reports in the literature of ureteral stricture when PCN surgery was performed for proximal ureteral stone. However, to our knowledge, this complication has never been reported after PCN with no direct ureteral instrumentation. We believe that the pelvic perforation with urine and fragments extravasation may have led to intense retroperitoneal end periureteral inflammation. After acute phase, periureteral scarring may have ensued leading to the extensive ureteral stricture found in our patient.

\section{CONCLUSION}

The present report showed a rare complication of PCN which may possibly be prevented by measures that reduce injuries to collecting system, thus avoiding urine extravasation and consequent late scarring. Moreover, the well established policy of trying to perform this procedure under sterile urine would also reduce the postoperative inflammatory process, and therefore the possibility of stricture formation.

\section{REFERENCES AND RECOMENDED READINGS ("of special interest, ** of outstanding interest)}

**1. LEE, W.J.; SMITH, A.D.; CUBELLI, V. et al: "Complications of percutaneous nephrolithotomy". AJR 148:177, 1987.

2. GREEN, D.F.; LYTTON, B.; GLICKMAN, M.: "Ureteropelvic junction obstruction after percutaneous nephrolithotripsy". J. Urol. 138:559, 1987.

3. WEIR, J.M.; D'A HONEY, R.J.: "Complete infundibular obliteration following percutaneous nephrolithotomy". J. Urol. 161:1274, 1999.

*4. WONG, MY.: "Evolving technique of percutaneous nephrolithotomy in a developing country: Singapoure General Hospital experience". J. Endourol. 12:397, 1998. 